travelled, but that they are distinctly related as cause and effect. This being true of the past, what can we say as to the future? Just as there is a lower heat limit below which iron capable of being usefully applied in the arts could not be produced, so there must be an upper limit, and I suggest that this limit is reached when our furnaces are capable of generating a temperature sufficient to volatilise the iron; it seems fairly obvious that heats higher than this cannot well be usefully employed. Such heats are, however, now readily attained in the electric furnace, and it would therefore seem that from this point of view the limiting condition has already been reached by the metallurgist. On the other hand, there seems but little inducement to increase the quantity of output, seeing that our potentialities of production appear to be now actually ahead of the world's requirements, and that there is every indication that even our present appliances will enable us to keep pace with any future demands.

I emphatically do not mean to imply that we have reached finality in the metallurgy of iron, but I do hold that future progress will have to be along different lines. Fortunately, we are already able to see what direction this progress must take. Recent advances have all been in the direction of improvement in quality and in the attainment of properties in which ordinary iron by itself is deficient. In other words, the future of the metallurgy of our metal will be directed, not by the crude methods of trial and error of the past, but by the application of principles developed by the methods of scientific research. For something like four centuries Great Britain has led the way in the great improvements in the iron industry along the old lines which I have been describing; we are, however, also the inventors of the science of metallography and of alloy steel; we may, therefore, fairly claim that even in modern scientific methods we are equally leading the world in the metallurgy of iron, and there is every reason to presume that the great work which members of the Iron and Steel Institute have done in the past in developing that iron industry which is the basis of our modern civilisation will still continue in the future, although, as I have suggested, that work will be carried on by means of modern methods and be based upon entirely different principles.

\title{
Progress of the Great Barrier Reef Expedition.
}

\section{By Dr. C. M. Yonge, Balfour Student, University of Cambridge}

$\mathrm{I}^{\mathrm{N}}$ the three months which have elapsed since the last report, the work of the Great Barrier Reef Expedition, in all its branches, has made excellent progress. Naturally, the weather conditions have not been so favourable as they were in the winter ; heavy rains and humid heat, with wet bulb readings so high as $86^{\circ} \mathrm{F}$., have been experienced, but work has been interfered with far less than was anticipated. The most serious drawback has been the state of the tides, the day low tides being very poor, which necessitated much collecting by night. On the other hand, sea work has proceeded without a hitch in spite of the previous gloomy accounts of the storminess of the summer months.

A great loss has been experienced in the departure from Low Island on Dec. 12 of $\mathrm{Mr}$. and Mrs. F. S. Russell and Mr. G. Tandy, who were compelled, owing to the termination of their leave of absence, to return to England. Dr. T. A. Stephenson has succeeded Mr. Russell as second in command, while Mr. A. P. Orr has taken over charge of the boat party, Mr. J. S. Colman carrying on Mr. Russell's work on zooplankton. 'There is, unfortunately, no professional botanist to succeed Mr. Tandy, though Miss Glynne is expected for two months later in the year; meanwhile Mrs. Stephenson is doing what she can to continue the collection of algæ. Mr. M. Spender, of the geographical section, is now with us permanently, while Miss E. A. Fraser, of University College, London, and Dr. S. M. Manton, of Cambridge, join us shortly. Both will work in co-operation with the reef party under Dr. Stephenson.

The regular plankton and hydrographic observations at the station 3 miles east of Low Island have been continued with scarcely an interruption; a further station has been worked in Trinity Opening, all from the Luana; while on two occasions the powerful motor launch Merinda has been hired from Cairns for work beyond the Barrier. For the hauling in of nets and hydrographic gear from deep water a friction winch with a small motor has been purchased, and this renders work both easy and relatively speedy.

At the inside station Mr. Orr reports that temperature has risen steadily to $29^{\circ} \mathrm{C}$. at the surface and $28.8^{\circ} \mathrm{C}$. in deeper water, while salinity has fallen and continues to fall as a result of the heavy rains. On several occasions there has been a definite gradient in temperature and salinity, accompanied by a fall in oxygen saturation in the deepest layers, though without any production of phosphate, but this has never lasted more than a week at a time or ever been considerable enough to withstand a wind of more than 20 miles per hour. The hydrogen ion concentration has remained steady throughout. Observations made at a depth of 600 metres beyond the Barrier showed that temperature was constant down to 50 metres, beyond which it fell rapidly to $10 \cdot 9^{\circ} \mathrm{C}$. at 600 metres. Below 50 metres, $p \mathrm{H}$ value and oxygen saturation sank and phosphate content rose. On Linden Bank, a coral formation beyond the Barrier and covered with 34 metres of water, the conditions were very similar to those inside the Barrier. The turbidity of the water is far less beyond than within the Barrier.

Miss S. M. Marshall and Mr. Colman are continuing routine work on the phytoplankton and zooplankton respectively. As the lack of nutrient salts in the water indicates, there has been no

$$
\text { No. 3107, VoL. 123] }
$$



plankton within the Barrier, while the numbers have been found even smaller in the open sea stations, there being little difference in type save for a few oceanic flagellates rarely found inside. The only notable change observed in the zooplankton occurred during the three weeks at the end of November and the beginning of December, when spatangid plutei appeared quite suddenly in vast numbers, the coarse silk townet catching just under 300,000 in a half-hour haul. It may be noted that dredging has revealed the presence of great numbers of a species of Lovenia in the mud around Low Island, one haul of the Agassiz trawl bringing in a catch estimated at about 20,000. Salps and Larvacea continue to fluctuate in an apparently irregular manner, and also copepods, which usually comprise numerically more than half the catch. On one occasion when planulæ were being extruded from Pocillopora on Low

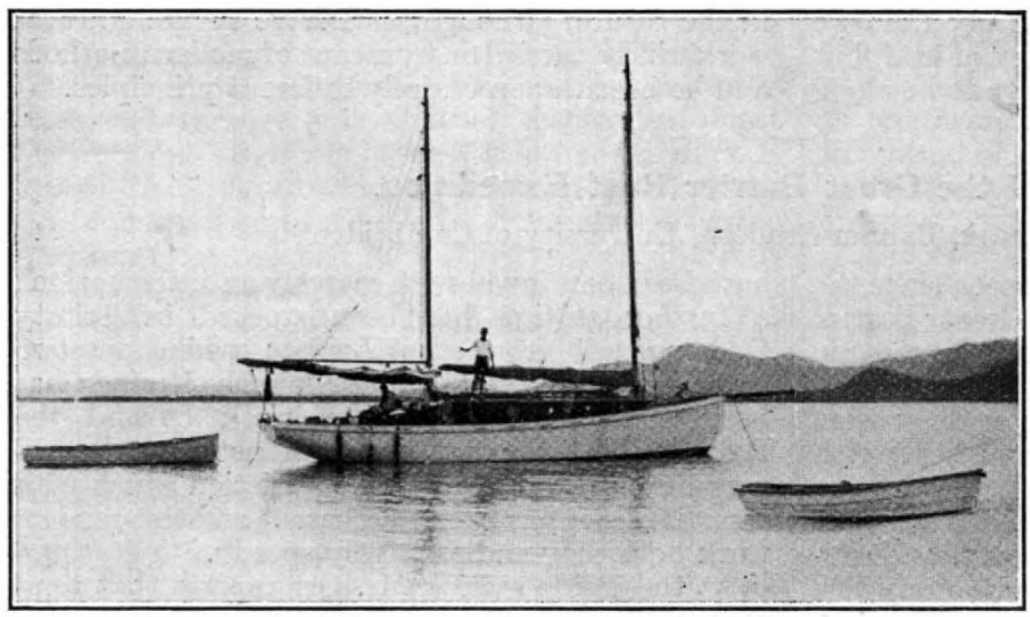

FIG. 1.-The Luana at anchor between Snapper Island and the mainland. significant change in the numbers of the phyto-

Other work by members of the boat party has included the exposure, by Mr. Orr, of jars for the collection of sediment, in selected areas on the reef flat and in the lagoon. These are collected weekly, and show clearly that the quantity of sediment is dependent on wind force and on the position of the jar, the sediment being mainly organic detritus mixed with some sand after stormy periods. The results from the various jars have so far been quite consistent and lend no support to the theory that abundant sediment is inimical to coral growth. Miss Marshall has done interesting work on the oxygen exchange of the planulæ of Porites, and found that, though their algæ produce a considerable amount of oxygen even at this stage, this does not balance the loss of oxygen due to respiration, also that more is produced in sunny than in dull weather.

Dr. T. A. Stephenson has completed a new type of experiment for observing the growth rate of corals. By the aid of the diving helmet, a number of colonies have been marked in particular ways in situ, working in about 12-20 feet of water. It may be suitably mentioned here that this helmet has proved of great value, particularly in connexion with Dr. Stephenson's work, but also in the collection of Mr. Orr's sediment jars and of corals for experimental purposes. Dr. Stephenson has continued his routine observations on the gonads of Favia and Symphyllia, and has made further progress with the ecological survey. Both Pocillopora and Porites have given off abundant crops of planulæ; numbers of these have been collected and reared, detailed observations

Island, some 3000 similar planulæ were caught in the coarse silk net. Again, on another occasion the numbers of Cavolinia rose from an average of less than 50 to 1200 .

Work over the reef flat by members of the boat party has been continued. Mr. Orr made a detailed study of a coral pool at spring tides, and found that, though there were very considerable changes in the hydrogen ion concentration, excess base, and temperature, there was no precipitation of calcium. There was a very low night tide and the oxygen saturation fell to 18 per cent, rising during the day to 230 per cent. In the mangrove swamp the oxygen content and $p \mathrm{H}$ value fell both by day and night during the low tides, instead of only during the day as in the coral region. Miss Marshall finds that the numbers of the phytoplankton in the anchorage remain low, such slight fluctuations as there are being without apparent cause. The zooplankton collected by Mr. Colman weekly has become progressively poorer in numbers and variety, though spatangid plutei and Cavolinia appeared at the same time as at the three-mile station.

\footnotetext{
No. 3107, VoL. 123]
}

being made as to the formation of young colonies from settled planulæ. He has been engaged on manifold constructional activities on the reef flat, particularly in connexion with the rearing and collection of planulæ and the observation of the spawning of reef animals. He has also made a new aquarium consisting of concrete tanks through which water runs continuously, this being particularly useful in connexion with Mrs. Stephenson's work on the reproduction of reef animals, which has been continued on the lines previously reported and also extended by the examination of various kinds of spawn collected on the reef.

The work on animals of economic importance now occupies practically the entire time of $\mathrm{Mr}$. F. W. Moorhouse. Although his farm of Trochus was unfortunately destroyed by stingrays, the previous six months had shown that the average increase in diameter of specimens ranging from $2 \mathrm{~cm}$. to $6 \mathrm{~cm}$. was no less than $2 \mathrm{~mm}$. per month, giving a yearly increase of about $2.5 \mathrm{~cm}$. Growth is continuous, and no disturbance rings are found on normal shells. He has been able to confirm these figures by the measurement at each full 
moon of some 600 animals taken at random, the measurements being graded into groups of $0.2 \mathrm{~cm}$. and the results recorded graphically. He has now 360 sponge fragments planted out. Some are suspended from lines, others are confined in 'houses' to test the effect of the elimination of direct sunlight. Regeneration of the fragments is remarkably rapid, the supporting cord being overgrown completely or partially in two days and the whole cut surface being overgrown in ten days. The growth rate of the local oysters is being studied, while weekly gonad examinations of Trochus niloticus, Holothuria atra, and two species of edible oyster have been made regularly, artificial fertilisations being successful in all save the first. He continues to take the temperature of the water in the anchorage twice daily, and this has risen as high as $33^{\circ} \mathrm{C}$., very near the lethal temperature of corals. During the recent low spring tides the temperature over the flat has risen above $35^{\circ} \mathrm{C}$. and a great many corals have been killed.

Assisted throughout by Mrs. Yonge and Mr. A. G. Nicholls, I have been able to make very material progress with my work. Little further work has been done on the feeding mechanisms of corals, but it has been found that Favia and Galaxea can digest planktonic organisms of 2-3 $\mathrm{mm}$. in length completely within twelve hours. The symbiotic algæ of corals possess a well-developed cellulose wall, have extensive reserve of fat, but no pure starch. A number of suitable corals have been fed with a variety of substances and polyps fixed after appropriate intervals with suitable fixatives,

for the later determination of the site and mode of absorption.

The monthly experiments on the change of oxygen content in the water surrounding corals kept for similar periods in light and darkness have been continued, and confirmatory experiments on the length of time which corals can survive sealing in jars in the sea have been carried out. A large light-tight box with a detachable lid, containing a small trap door, has been cemented down on the reef flat, the object being to obtain data on the effect of continued darkness on the oxygen content and hydrogen ion concentration of the water surrounding the corals and clams (which also contain algæ) placed in the box.

Work on the digestive enzymes of corals has been almost completed, extracts of the mesenterial filaments of Lobophyllia, and fluid from the cœlentera of large Fungia being studied. In the former there is a powerful protease, of which the optimum hydrogen ion concentration has been found, an extremely weak lipase, and enzymes capable of digesting-very slowly-starch and glycogen but no other carbohydrate; the tem- perature of destruction and the optimum hydro. gen ion concentration of the former have been determined. Apparently the extract has no action on the symbiotic algæ. Enzymes in the cœlentera of Fungia are confined to protease, apparently the only extracellular enzyme.

Most interesting results have been obtained from the experiment on the effect of starvation and feeding on similar corals kept in light and darkness. The starved corals receive twice filtered sea water twice daily, while the others receive unfiltered water to which is added every other night the results of a townetting. Fungia, Favia, Psammocora, and Galaxea have all given good results, and demonstrated that fed corals continue in perfect condition in both light and dark, paling somewhat in the latter owing to the death of the algæ, but starved corals quickly begin to shrink in the tissues, undamaged algæ being extruded in great numbers and the tissues consequently turning 
Mr. Spender, who had the assistance of Mr. E. C. Marchant until Jan. 9, has been busily engaged on his large-scale map of the island, a slow and laborious task. Owing to the humidity causing distortion of the drawing paper, he has to plot all points by co-ordination. He has taken several traverses with the tacheometer between triangulation points, the fringe of the island being almost completely mapped, and hopes to fill in the central detail by plane-tabling later. $\mathrm{He}$ is running level traverses of a precise order across the flat.

A preliminary bore with a hand plant has been made in the centre of the sand cay, 13 feet of casing being sent down, and although a level below that of the 'beach rock' was reached, nothing but sand was encountered.

The tide gauge has been put up after great labour, entailing the erection, with the assistance of a member of the lighthouse staff, of three 30 -foot mangrove poles in the form of a tripod. This is giving excellent and most interesting results, and it is now possible to refer any point on the island to mean sea-level, while sounding operations are also possible.

At the time of writing, the work of the Expedition is being greatly extended by the hiring of a powerful Townsville launch, the Magneta, for plankton, hydrographic, and dredging cruises as far north as Cook's passage north of Cooktown.

\section{Obituary.}

\section{Col. E. Lester Jones.}

$\mathrm{T}$ HE untimely death of Col. E. Lester Jones, on April 9, meant a loss to the scientific world of a friend and ally whom it will not be easy to replace. Col. Jones had been for fourteen years the directing head of the United States Coast and Geodetic Survey, and in that capacity had used his talent and energy to promote scientific work and investigation. Much of the increased activity and interest in hydrography, geodesy, seismology, and terrestrial magnetism may be traced directly to his influence.

Just as it is not possible to gauge the ultimate value of any single scientific discovery, just so is it out of the question to attempt an immediate appraisal of the importance of any one man's life work in the interests of science. A hint of the monument Col. Jones builded for himself may be found in the splendid organisation the destinies of which he guided for fourteen years. The United States Coast and Geodetic Survey, pioneer Government scientific bureau, is to-day functioning efficiently; it is well organised, well equipped, and making rapid forward strides. For this, the credit must inevitably gravitate toward the man who led, ever encouraged, and efficiently aided its scientific staff.

Col. Jones was born at East Orange, New Jersey, on April 14, 1876. In addition to extended study abroad, he held an A.B. degree and an honorary A.M. degree conferred by Princeton University, and was commissioned a hydrographic and geodetic engineer. In 1913 he was appointed deputy commissioner of the Bureau of Fisheries, holding that position until being appointed the directing head of the United States Coast and Geodetic Survey by President Wilson in 1915.

In addition to his administrative work with this latter bureau, he was the American member of the International Boundary Commission appointed to fix the boundary between the United States, Alaska, and Canada. He had also been a member of several important Government and scientific missions. One of the last of these was his appointment as a delegate to the twelfth International Geographical Congress held at Cambridge last year.

\section{Dr. Charles Beavis.}

The sudden death of Dr. Charles Beavis on April 17 at his residence, Naishcombe House, Wick, Bristol, came as a great surprise to those who had recently seen him, apparently in the best of health and full of life and vigour. He was born at Hampstead on May 3, 1869, and educated at Atherstone Grammar School. At the age of seventeen he went to Coblenz, then to Bonn, where he read chemistry, physics, and mineralogy under Kekulé, Anschutz, Klinger, Bendes, Clausius, and Hertz. He afterwards proceeded to Würzburg, working under Emil Fischer, and in 1892 took the degree of Ph.D. (Magnam Laudem). He returned to London and worked for seven years with Dr. Quirin Wirtz, during which time he took his F.I.C. in 1897. In 1899 he went to Wick to start a fine colour department in the Golden Valley Ochre and Oxide Co., becoming manager in 1902, taking over the business in 1904. Although records of published original work are not available since his graduation, Dr. Beavis had publicly identified himself with chemistry and the intricate problems of modern colour manufacture, and for many years took keen interest in the Colour Makers' Association of the United Kingdom, of which he was the first and only chairman.

WE regret to announce the following deaths:

Prof. John W. Harshberger, professor of botany in the University of Pennsylvania and president in 1926 of the American Ecological Society, aged sixty years.

Dr. F. C. Madden, C.M.G., Dean of the Faculty of Medicine, Egyptian University, Cairo, an authority on bilharziosis and schistosomiasis, on April 27, aged fifty-six years.

Dr. August von Schmidt, formerly director of the meteorological-geophysical section of the Württemberg State Statistical Bureau at Stuttgart, on Mar. 21 , aged eighty-nine years.

Sir George Syme, K.B.E., president of the College of Surgeons of Australasia and chairman of the Royal Commission on Health, Commonwealth of Australia, aged sixty-nine years.

Dr. Ludwig Wittmack, honorary professor of botany in the University of Berlin and author of the section on the Bromeliaceæ in Engler and Prantl's " Pflanzenfamilien ", on Feb. 2, aged eighty-nine years. 